This is the author's final, peer-reviewed manuscript as accepted for publication. The publisher-formatted version may be available through the publisher's web site or your institution's library.

\title{
Process control in cell culture technology using dielectric spectroscopy
}

Justice, C.1, Brix, A.2,4, Freimark, D.1, Kraume, M.3, Pfromm, P.2, Eichenmueller, B.4, Czermak, P.1,2

${ }_{1}$ Institute of Biopharmaceutical Technology, University of Applied Sciences GiessenFriedberg, Germany

${ }_{2}$ Department of Chemical Engineering, Kansas State University, Manhattan, KS, USA ${ }_{3}$ Department of Chemical Engineering, University of Technology Berlin, Germany ${ }_{4}$ Boehringer Ingelheim Vetmedica, Inc., St. Joseph, MO, USA

\section{How to cite this manuscript}

If you make reference to this version of the manuscript, use the following citation format:

Justice, C., Brix, A., Freimark, D., Kraume, M., Pfromm, P., Eichenmueller, B., Czermak, P. (2011). Process Control in Cell Culture Technology Using Dielectric Spectroscopy. Retrieved from http://krex.ksu.edu

\section{Published Version Information}

Citation: Justice, C., Brix, A., Freimark, D., Kraume, M., Pfromm, P., Eichenmueller, B., Czermak, P. (2011). Process Control in Cell Culture Technology Using Dielectric Spectroscopy. Biotechnology Advances, 29(4), 391-401.

Copyright: @ 2011 Elsevier Inc. All rights reserved

Digital Object Identifier (DOI): doi:10.1016/j.biotechadv.2011.03.002

Publisher's Link: www.elsevier.com/locate/biotechadv/

This item was retrieved from the K-State Research Exchange (K-REx), the institutional repository of Kansas State University. K-REx is available at http://krex.ksu.edu 


\section{Process Control in Cell Culture Technology \\ Using Dielectric Spectroscopy}

Justice, $C_{\cdot 1}$, Brix, $A_{\cdot 2,4}$, Freimark, D.1, Kraume, $M_{\cdot 3}$, Pfromm, $P_{\cdot 2}$, Eichenmueller, B.4, Czermak, $P_{\cdot 1,2}$

${ }_{1}$ Institute of Biopharmaceutical Technology, University of Applied Sciences Giessen-Friedberg, Germany

${ }_{2}$ Department of Chemical Engineering, Kansas State University, Manhattan, KS, USA

${ }_{3}$ Department of Chemical Engineering, University of Technology Berlin, Germany

${ }_{4}$ Boehringer Ingelheim Vetmedica, Inc., St. Joseph, MO, USA

\section{Corresponding Author}

Prof. Dr. Peter Czermak, University of Applied Sciences Giessen-Friedberg. Wiesenstrasse 14, 35390 Giessen, Germany. Tel: +49 641-309-2551, fax: +49 6413092553; email: peter.czermak@tg.fhgiessen.de;

\section{Abstract}

In the biopharmaceutical industry, mammalian and insect cells as well as plant cell cultures are gaining worldwide importance to produce biopharmaceuticals and as products themselves, for example in stem cell therapy. These highly sophisticated cell-based production processes need to be monitored and controlled to guarantee product quality and to satisfy GMP requirements. With the process analytical technology (PAT) initiative, requirements regarding process monitoring and control have changed and real-time in-line monitoring tools are now recommended. Dielectric spectroscopy (DS) can serve as a tool to satisfy some PAT requirements. DS has been used in the medical field for quite some time and it may allow real-time process monitoring of biological cell culture parameters. DS has the potential to enable process optimization, automation, cost reduction, and a more consistent product quality. Dielectric spectroscopy is reviewed here as a tool to monitor biochemical processes. Commercially available dielectric sensing systems are discussed. The potential of this technology is demonstrated through examples of current and potential future applications in research and industry for mammalian and insect cell culture.

Keywords: dielectric spectroscopy, cell culture technology, PAT, biomass monitoring, process control 


\section{Introduction}

Animal-, plant-, and insect cell cultures have become significant tools in the production of proteins and biopharmaceuticals for applications involving humans [Baldi et al., 2007, Daniell et al., 2001, Walsh, 2006, Wurm, 2004]. Animal cell lines, such as Chinese hamster ovary (CHO), hybridoma, human embryo kidney (HEK) or baby hamster kidney (BHK) cells are commonly used as production cells [Baldi et al., 2007, Butler, 2005, Walsh, 2006, Wurm, 2004]. Whole cells may also be the target product for example in stem cell therapy [Weber et al., 2007b]. Insect cells, which are for example used for the production of recombinant proteins, viruses or viral components [Nehring et al., 2006] are currently gaining an increased importance in the field of regenerative medicine [Negrete and Kotin, 2008, Stanbridge et al., 2003], especially in gene therapy [Alexander et al., 2007, Edelstein et al., 2007, Stanbridge, et al., 2003]. Cells may be grown in suspension, on surfaces, or even in threedimensional solid matrices. Standard production units include stirred tank reactors, fixed and fluidized bed reactors, airlift reactors, wave reactors, spinner flasks, roller bottles, and Erlenmeyer type shake flasks.

The production processes for cells or cell related products are complex, and must comply with GMP requirements [Baldi, et al., 2007, Butler, 2005, Weber et al., 2008, Weber et al., 2007a, Weber, et al., 2007b, Wurm, 2004]. The intricate relationships of process parameters and process outcome may not be clear in all cases, especially on the industrial scale. However, for clinical applications when implementing research results on a larger scale, not only quality but also sufficient product quantity recombinant protein, virus or cell - has to be delivered by monitored and controlled processes satisfying GMP.

Any tool that can contribute to supply direct on-line information on the biological state of a cell culture is extremely valuable. Dielectric spectroscopy (DS) can serve as such a tool with the advantages of rapid non-contact measurements that can be automated through a variety of sterilizable commercial sensors and systems.

\subsection{Process Monitoring and Control}

Process monitoring is an important tool for process characterization to demonstrate the robustness of manufacturing processes by establishing the relationships between key operating parameters and the desired product. To receive regulatory approval for a specific biopharmaceutical production process, process monitoring is generally required for documentation purposes. Cell growth, productivity (yield), product quality, medium conditions (temperature, $\mathrm{pH}, \mathrm{pO}_{2}, \mathrm{pCO}_{2}$ ) and level of metabolites (glucose, glutamine, lactate, ammonia) are examples of important parameters for biopharmaceutical process characterization. These parameters are also important for subsequent legally required process validation [Li et al., 2006]. Many cell culture based processes are operated in perfusion or fed-batch mode, where control of the perfusion or feed addition rate is required to maximize recombinant protein production [Carvell and Dowd, 2006]. Biological systems are very sensitive to many process changes. The fundamental understanding of the intricate relationships between the very significant number of process parameters and the ultimate desired process outcome is often not complete. Kinetics and mass balances are sometimes difficult to obtain and describe. Despite heroic efforts to achieve reproducibility growth rates in cell cultures are often not easily reproduced and controlled [Butler, 2005].

These issues may be tackled through process monitoring. A simple example would be to monitor the temperature in a fermentation vessel, while a complex example may be the virus titer as a function of time. Even the apparently simple monitoring of temperature which is fairly easily achieved in the laboratory causes issues for scale-up since in larger physical systems the temperature will more likely show spatial inhomogeneities. Improved process monitoring can help to accelerate process development, and aids in achieving efficient production of consistently high quality products [Baldi, et al., 2007, Hoeber, 1910]. 


\subsubsection{Methods of Monitoring}

The key parameters to be monitored in cell culture are substrate and metabolite concentrations, temperature, $\mathrm{pH}$, oxygen and carbon dioxide partial pressures, protein concentration and especially the concentration and state of entities such as cells or virus [Czermak et al., 2009]. This list is certainly not complete as far as the impact on cell culture is concerned. Conductivity or electrolyte content, trace minerals, and viscosity could be other examples and other significant parameters will surely emerge in the future.

Methods to monitor biochemical process parameters described in the literature can be roughly categorized as in-line, on-line, at-line and off-line analysis. In the case of in-line analysis the detector is directly interfaced to the process, while in on-line analysis process liquid is directed continuously through some kind of a recirculation loop past the detector and back to the process. At-line analysis is performed on a sample removed from the process and using an instrument in close physical proximity to the process (quasi-on-line) while for off-line analysis the sample is removed from the process and is transported to a remote location for analysis [Vojinovic et al., 2006]. Common methods for substrate and metabolite determination as well as product concentration analysis are briefly described below with a focus on methods for monitoring cell concentration and biomass.

\subsubsection{Substrate and Metabolite Concentration}

Standard substrates, e.g. glucose, glutamine and oxygen, and metabolites, e.g. lactate, ammonia, glutamate, oxygen, and carbon dioxide, are mostly determined by on-line and off-line methods using common probes, standard assay kits as well as chromatographic methods (HPLC, Ion Chromatography). Different glucose sensors (off-line and on-line) are available [Folly and B., 1996, Male et al., 1997, Pickup et al., 2005], but stability, calibration and validation of these probes remains an issue [Renneberg and Lisdat, 2008]. An example for a PAT-tool for glucose measurement is a continuous flow injection analysis based on chemiluminescence [Huang et al., 1991]. In-line methods to determine the concentration of glucose, glutamate, prolin, lactic acid, ammonia, and dissolved carbon dioxide are photometric infrared (IR) and near-infrared (NIR) spectroscopy which both conform to PAT requirements [Rathore et al., 2008]. Infrared spectroscopy suffers significantly from possible interference of background compounds [Boudreau and Benton, 2008, Vojinovic, et al., 2006]. Information gained from substrate consumption and base addition for $\mathrm{pH}$ stabilization was used as an indirect method to determine cell growth and cell concentration in a perfused system [Kussow et al., 1995].

\subsubsection{Protein Concentration}

Product (protein) concentration is commonly measured by HPLC, which conforms to PAT requirements [Rathore, et al., 2008] or ELISA [Li, et al., 2006]. Raman spectroscopy can be used inline to monitor the homogenization process of an active pharmaceutical ingredient (API) according to Beer et al., 2006. Here the method also helped to understand the production process better [De Beer et al., 2006]. Several applications of Raman spectroscopy are reported as a PAT tool for process optimization, understanding, monitoring, and control [Rathore, et al., 2008].

\subsubsection{Cell and Biomass Concentration}

The biomass concentration is one of the centrally important parameters of cultivation processes. Realtime measurements are important for this key parameter [Gnoth et al., 2007]. Today, several in-line measurement methods are available to determine cell number and cell size distributions in biological processes. Most of these methods are based on image analysis. Examples are focused beam reflectance measurement, particle vision, and different types of in-situ microscopy. In all cases realtime analysis is possible, but these approaches are only suitable for well mixed systems, where homogeneity can be assumed throughout the process since only a very small volume fraction is generally monitored. On the other hand, these approaches may allow the monitoring of potential morphological changes of cells during the process in addition to cell concentration and volume. Optical sensors are unfortunately often prone to fouling especially over long culture times and are sensitive to changes in turbidity, light dispersion, presence of variable amounts of cell debris, gas bubbles, and similar interferences along the light path [Carvell and Dowd, 2006, Vojinovic et al., 2006]. Other 
measurement principles include optical density measurements, acoustics, laser light- Raman-, and fluorescence spectroscopy [Vojinovic et al., 2006]. Infra-red sensors have also been described, but their range of cell concentrations is rather limited. Laser turbidity measurements are suitable for high cell density cultures [Carvell and Dowd, 2006]. Until 2002, most methods for the monitoring of cell concentrations were not applicable to immobilized cell cultures using microcarriers or other fixed bed carriers. Common methods now allowing the monitoring of these cultures include some optical techniques (see above) based on light absorbance and/or scattering, real-time imaging, particle size analysis and measurements of culture fluid density [Ducommun et al., 2002a].

Established off-line measurement methods for cell concentration determination are for example Cedex ${ }^{\circledR}$ by Roche Applied Sciences, and various systems by Beckmann Coulter [Rudolph et al., 2007]. The obvious drawback of these methods is the delay between sampling and the availability of results as well as the risk of contamination [Vojinovic et al., 2006]. Indirect methods, such as DNA concentration determination or fluorescent based measurements have been described [Myers, 1998, Rengarajan et al., 2002, Zipper et al., 2004]. Furthermore indirect off-line methods, where the determination of the oxygen partial pressure, lactate or glucose concentration in the medium is used to monitor the process and to indirectly calculate the cell concentration have been described [Vojinovic et al., 2006].

Not only is the concentration of the cells of importance for the process, but also their viability. Different off-line methods for viability measurement can be categorized into permeability assays, functional assays, reproductive assays, and morphological assays [Cook and Mitchell, 1989].

Biopharmaceutical production processes are generally overseen by agencies such as the Federal Drug Administration in the U.S. (FDA) and the European Medicines Agency (EMEA) and must satisfy GMP requirements. The methods summarized above must satisfy the requirements of the respective agencies. In recent years, these requirements have changed and new initiatives arose, such as the Process Analytical Technology (PAT) described in detail below.

\subsubsection{Process Analytical Technology}

The Process Analytical Technology (PAT) initiative was introduced by the FDA in 2004 and has been supported by the EMA, the Japanese Ministry of Health, Labor and Welfare (MHLW), and by the International Conference on Harmonization (ICH) guidelines [Rathore et al., 2008]. With this initiative, increased requirements for bioprocess monitoring were implemented to improve the understanding and control of biology-based manufacturing processes [Clementschitsch and Bayer, 2006]. The PAT initiative was started within the "GMP-Initiative for the 21st Century". PAT can be described as a tool for designing, analyzing, and controlling manufacturing through timely measurements of critical quality and performance parameters with the goal of ensuring final product quality.

Present GMP standards are usually empirical and not scientifically confirmed [FDA, 2004]. Details on biopharmaceutical production processes are often not entirely known and are difficult and/or costly to establish. Small variations in a culture's progress due to subtle changes in process parameters are often not tracked since on-line monitoring is generally limited to relatively simple parameters such as temperature, $\mathrm{pH}$, and dissolved oxygen. This limitation of on-line information is especially critical for biological systems, as they are subject to significant variations in their growth- and/or production rates due to small variations in process parameters that are below detection limits or are not monitored at all [FDA, 2004].

The FDA describes the goal of PAT as follows: "The goal of PAT is to understand and control the manufacturing process, which is consistent with the current drug quality system: quality cannot be tested into products, it should be built-on or should be by design" [Douennebier 2007, FDA, 2004]. The tools described by the FDA to reach PAT goals are multivariate tools for design, data acquisition and analysis, process analyzers, process control tools, continuous improvement, and knowledge management tools. In combination, PAT allows the control of the production process and its quality assurance [Kourti, 2006]. A better process understanding, improved yields, and minimization of waste, 
rejects and reprocessing will result in overall cost reduction and on-time release of batches [Rathore et al., 2008]. The FDA suggests key PAT technologies: near infra-red spectroscopy (NIR), UV-VIS, NMR, MS, HPLC, fluorescence measurements, and imaging technology [Boudreau and Benton, 2008, FDA, 2004, Kourti, 2006, Rathore et al., 2008] promoting process understanding and process control for improved consistency of process performance and product consistency [Rathore et al., 2008]. Recent reviews on trends in PAT and PAT in biopharmaceutical processes are available [Chew and Sharratt, 2010, Rathore et al., 2008].

The application of DS for bioprocess monitoring is emerging as a promising tool for PAT [Clementschitsch and Bayer, 2006, Teixeira et al., 2009].

\section{Impedance Spectroscopy as a Tool for PAT}

Perhaps one of the more critical areas of biochemical engineering is the "upstream" section where the product (ranging from a molecule to a whole organism) is produced. This part of the process is the origin of impurities etc. that lead to significant separation and purification issues "downstream" [Rathore et al., 2008]. A promising tool for the on-line monitoring of cell cultures and biomass properties is DS, allowing non-invasive and non-destructive continuous process monitoring in bioreactors for suspension cultures and even cells attached to solid carriers [Carvell and Dowd, 2006].

DS has been used industrially for some time to monitor the viable cell density for example of yeast in the brewing process [Heggart et al., 2000, Austin et al., 1994]. The application of DS has already been discussed in the context of PAT [Boudreau and Benton, 2008, Gnoth et al., 2007] and has been suggested as a possibly accurate and reliable method for online monitoring of viable cell density in cell manufacturing processes [Carvell and Dowd, 2006]. Examples include cell cultivation on solid surfaces, on microcarriers in suspension, on porous glass carriers in fluidized bed reactors, and on porous discs in a fixed bed reactor. Reviewed cell types include bacteria, yeast, mammalian, and insect cells [Carvell, 2008, Carvell and Dowd, 2006, Ducommun et al., 2001, Fehrenbach et al., 1992, Noll and Biselli, 1998, Sarra et al., 1996, Zeiser et al., 1999].

The potential of DS, however, may well reach beyond measuring viable cell density to more intricate issues such as the physiological state of the cell or organism.

\subsection{Basic Theory of Impedance Spectroscopy}

\subsubsection{Physical Principle and Applications}

DS is based on the measurement of the passive dielectric properties of substances or biological units in a conducting medium. The term basically describes the measurement and analysis of the electrical capacitance and conductivity over a certain range of frequencies. The sample, called the dielectric, is placed in the electrical field between two electrodes. The change in the electric current-voltage relation in the presence of an alternating electrical field is then used to derive information on the sample. The focus of DS can either be the material that is placed between the electrodes, or the electrode interface itself. The electrode interface is investigated by DS techniques in corrosion research [Mansfeld, 2006]. This is a significant application of DS. The dielectric material placed between the electrodes is the focus of attention for applications ranging from materials such as cement paste to the yeast suspensions in brewing, and to cell cultures as discussed here.

The basic idea of DS is to apply a periodically alternating electrical field, perhaps at various frequencies, to a system (an aqueous cell suspension for example in our case). This is somewhat similar to application of an alternating mechanical stress at different frequencies to a solid material as in dynamic mechanical analysis of polymers, for example. The system for DS can be an entire multicellular organisms such as a human in medical applications of DS, or in the case of interest here a solution/suspension containing suspended or supported cells or unicellular organisms at least some of which are alive, along with low molecular solutes (salts, nutrients) and perhaps cell debris, virus, 
and virus particles. If the frequency is in the correct range, then some components in the medium can respond for example by storing some energy as temporarily separated charges (polarization). When the electrical field is periodically reversed then some lag in the system response is detected (amplitude and/or frequency changes). This response is the basis of dielectric spectroscopy.

The AC electrical field applied to the samples may cause, depending on the frequency and field strength, a polarization, orientation or displacement of electrically charged entities that may range from single inorganic ions to whole cells or even multi-cell organisms. In the range between $0.1-10 \mathrm{MHz}$, the method is termed radio frequency impedance spectroscopy (RFI) and the polarization of non conducting entities with surfaces, such as cell membranes, occurs [Arnold, 2001]. This range represents a small fraction of the wide range of frequencies possible with DS. Intermediate wavelengths cause the change of orientation of dipoles while near infra-red and infra-red frequencies cause atomic relaxation. Electronic relaxation is observed in the range of visible light (see fig. 1) [Doerner, 2008].

It is qualitatively simple to recognize that at very high frequencies the system has no time to respond and no signals of interest are observed, while at very low frequencies the physical changes in the system are in phase with the change of the external field polarity and no useful signal is observed either.

In the radio frequency range, cells with intact plasma membranes basically act as capacitors, since the non-conducting nature of the generally lipid-based cell plasma membrane allows the buildup of charge [Noll and Biselli, 1998]. Living organisms actively maintain electrochemical potential differences across their membranes. The cell's dielectric properties give important information about the cell's physiology, in particular the properties of the membrane and the cell interior. Values that can be determined are the membrane capacitance $C_{\text {mem }}$, the effective membrane conductance $G_{\text {mem }}$ and the intracellular conductivity $\sigma_{1}$. DS can also be applied to non-biological membranes for example to investigate subtle surface fouling [Watkins and Pfromm, 1999]. The membrane capacitance of living cells generally describes the amount of charge that can be stored across the cell membrane in an applied alternating electric field and is highly dependent on among other parameters on the folding of the membrane. The effective membrane conductance gives a measure of the permeability of the cell membrane, where movements of ions along the membrane also play a role. Capacitance values of viable cells with intact membrane are very high compared to non-viable cells, so that nonviable cells, leaking cells, cell debris, evolved gas bubbles and other media components are essentially invisible to RFI [Carvell, 2008, Ducommun et al., 2001, Ducommun et al., 2002a]. Finally, the mobility of ions in the cytoplasm determines the intracellular conductivity. Exchanges between the cytoplasm and the exterior may be monitored as these values change [Hoeber, 1910, Patel and Markx, 2008].

Fig. 2 describes the dependency of the capacitance signal of a biological sample with spherical cells as a function of the radio frequency. The increase in capacitance from high to low frequencies displays a sigmoid shape and is known as the ß-dispersion [Cannizzaro et al., 2003, Davey et al., 1993a, Esteban et al., 2008]. At low frequencies, the polarization process is slow, so that the resulting capacity is high. The working point for RFI-based sensors is near the critical frequency $f_{c}$. At high frequencies, there is hardly any polarization and only background capacitance due to the dipoles of water or other small molecules in the suspending medium is detected [Carvell and Dowd, 2006]. If an alternating electric field is applied, then the resulting capacitance is measured and is dependent upon the cell type, the cell size and, in a certain range, it is proportional to the concentration of the viable cells (see fig. 2) [Carvell, 2008]. The dependency of the signal on the cell size is shown in fig. 3 . When measured at a fixed frequency close to the average $f_{c}$, the capacitance is independent of cell size.

In the case of adherent growing cells, signals differ from single suspended spherical cells. Ron et al. describe models for aggregation effects of spherical cells. Two models are described, were one simulates changes in the cell membrane being similar to anchoring junctions by adjacent cells. The strength of permittivity decreases significantly in comparison to spherical cells suspended in a homogenous solution, and a shift in the critical frequency is found [Ronet al., 2009]. Cell adhesion 
experiments show similar results, describing smaller capacitance values for adherent cells than for suspended essentially spherical cells [Ehret et al., 1998].

\subsubsection{Mathematical Description of Dielectric Spectroscopy}

The detailed mathematical description of DS has been discussed in the literature and in textbooks [Arnold, 2001, Coster et al., 1996, Davey et al., 1993a, Davey et al., 1993b, Marszalek et al., 1990, Pethig and Kell, 1987, Barsoukov and Macdonald, 2005]. An overview is given below.

DS is based on the measurement of passive electrical properties of a material, the capacitance $C$ and the conductance $\mathrm{G}$ (generally for $0.1-10 \mathrm{MHz}$ ). Both variables depend on the properties of the system that is investigated but also on the geometry and the size of the measuring electrodes, and on interactions at the electrode/system (here medium or broth) interface. The relative permittivity $\varepsilon_{\mathrm{T}}$ and the conductivity $\kappa$ describe the relation independent from the electrodes given by the following equations:

$$
\begin{gathered}
\mathbf{C}=\varepsilon_{\mathrm{T}} \varepsilon_{0}\left({ }^{A} / \mathrm{d}\right) \\
\mathbf{G}=\kappa(A / \mathrm{d})
\end{gathered}
$$

for plane-parallel electrodes where the area $A$ is separated by distance $d$ and the constant $\varepsilon_{0}$ is the permittivity of a vacuum $\left(\varepsilon_{0}=8.854 \mathrm{pF} \mathrm{m}^{-1}\right)$. In 1957, Schwan correlated the capacitance of a suspension of ideal spherical cells with radius $r$ and the capacitance per membrane unit area $C_{m}$ as:

$$
\mathrm{C}=9 / 4 \mathrm{rPC}_{\mathrm{m}} \mathrm{d} / \mathrm{A}
$$

where $P$ is the volume fraction of the cells in the suspension volume between the parallel plates of area $A$ and distance $d$ and is defined by the cell volume $\left(4 / 3 \pi r^{3}\right)$ and the cell density per unit volume $N$, so that the capacitance is a function of the cell radius and correlates linearly with the cell density and capacitance per membrane unit area:

$$
\mathrm{C}=3 \pi \mathrm{rr}^{4} \mathrm{NC}_{\mathrm{m}} \mathrm{d} / \mathrm{A}
$$

[Noll and Biselli, 1998]. A detailed description including the real and imaginary part of the complex impedance can be found elsewhere [Hoeber, 1910].

To establish a mathematical correlation of the capacitance signal to the desired biological and/or physical variables, a complex mathematical correlation is necessary, which is based on reference sample analysis for each of the desired parameters via established analytical methods [Ansorge et al., 2007, Cannizzaro et al., 2003, Ducommun et al., 2002a, Esteban et al., Noll and Biselli, 1998].

Clearly, both the medium and the cells or organisms (on carrier particles or suspended) impact the overall electrical properties of a suspension placed between the electrodes of a DS setup. In a dilute system (with respect to cell density) the direct-current resistance will for example be governed by electrolytes and especially salt concentrations in the liquid. The capacitance or ability to at least temporarily store electrical energy by charge separation, however, will exist mainly across cell membranes of living organisms.

\subsection{Probes and Instrumentation}

The DS technology allows a wide range of applications, but for sterile biopharmaceutical production processes, GMP requirements must be fulfilled. GMP compliant DS probes for commercial industrial bioprocesses are to the author's knowledge currently available from two manufacturers: Aber Instruments, Aberystwyth, UK, and FOGALE nanotech, Nimes, France. Both offer a range of instruments for the brewery and biotech industry but the focus is here on the instruments specifically developed for biotechnology. 
Aber Instruments currently offers the Biomass Monitor 200, 210, 220 and 230 for in-line monitoring of biomass in bioprocesses. 12 and $25 \mathrm{~mm}$ diameter in situ steam sterilizable probes with an annular ring electrode configuration in various lengths are available. The instruments can be used with pre-set working frequencies for different types of cultures (bacteria, yeast or animal cell culture) but the more advanced models are also capable of performing a frequency scan. Depending on the model, up to four bioreactors can be monitored simultaneously with one instrument. Recently the company has introduced the new Futura line with improved accuracy and life cycle tracking for the probe.

FOGALE nanotech's Biomass System and Biomass System Pro have the option to connect up to four probes and allow frequency scanning. A range of stainless steel probes in various lengths for a variety of standard bioreactor ports is available. FOGALE nanotech has announced the introduction of the new BIOMASS 100, 465 and the BIOMASS PRO (see fig.4) with free choice of working frequency, and monitoring of sterilization cycles and hours of operation [Ansorge et al., 2007].

In addition, in 2008, a modular concept was announced for process instrumentation with broad bandwidth DS, designed for the integration in industrial plants. It utilizes multi-sinus technique $(10 \mathrm{~Hz}-$ $10 \mathrm{MHz}$ ) and maximum length correlation for the high frequency range up to $5 \mathrm{GHz}$. The instrument performance is comparable to that of commercial network analyzers and being connected to a PC, they are also a versatile and affordable laboratory instrument [Nacke et al., 2008].

\subsubsection{Disposables}

The instrument manufacturers for DS equipment follow the market trend towards disposable probes. This eliminates the need of cleaning in place (CIP) sterilization in place (SIP), and may result in operating cost reduction. As trends in the pharmaceutical industry show, the use of disposable units for production processes is increasing and cGMP and GMP guidelines support their application. In 2008, Aber Instruments introduced a viable biomass probe for the increasingly popular disposable bioreactors. This probe is compatible with the Hyclone Single Use Bioreactor (HyClone Laboratories, Inc., Logan, Utah, U.S.A.). A standard reusable probe is available that can be inserted into the bag through a Pall Kleenpak connector (see fig. 5). A flow-through silicone tubing bypass loop can also be used, and a weldable probe for bags and other single-use bioreactors is available [Aber Instruments, 2008] (fig. 5). A similar probe for single use reactors is available from Fogale (fig. 6).

\subsection{Applications}

\subsubsection{Applications in Research}

Various applications of DS in cell culture research are described, going back to the early $20^{\text {th }}$ century, when Hoeber [Hoeber, 1910] compared the low and the high frequency conductivity of erythrocytes and demonstrated the existence of the cellular membrane based on electrical properties. Nowadays, not only process monitoring in production processes, but also monitoring on the cellular level is described, such as differentiation processes of mesenchymal stem cells [Hildebrandt et al., 2010], dielectric membrane phenomena [Zhuang et al., 2010] and electrical properties of cells in general [Heubach et al., 2004, Wang and Jang, 2009]. Often, systems are described, where cells are grown on microplates or other small units with integrated electrodes, where the dielectric properties of single cells can be monitored. To assess cell adhesion and morphological changes of mouse cells, immortalized fibroblasts [Ceriotti et al., 2007a], cardiomyocytes [Qui et al., 2008], and mammalian cancer cells [Rahman et al., 2008] were monitored in a 96-well plate and in small volume detection chambers, where probes are integrated [Ceriotti et al., 2007a, Ehret et al., 1997, Ehret et al., 1998, Guo et al., 2006, Yu et al., 2006]. Furthermore, the monitoring of apoptosis and necrosis [Lee et al., 2009, Qu et al., 2009] as well as monitoring of cytotoxic effects of various substances by DS have been described [Ceriotti et al., 2007b, Liu et al., 2009, Malleo et al., 2009]. Examples for the on-line monitoring and study of morphological changes of cells induced by receptors, such as the $G$-Protein coupled receptors on HeLa and CHO cells [Yu et al., 2006], as well as the analysis of a protein kinase inhibitory effect on 3T3 fibroblast cells [Huang et al., 2003] in microchambers equipped with DS electrodes have been reported [Huang et al., 2003, Yu et al., 2006]. The successful assessment of tissue growth within microporous polymer scaffolds has been reported [Dziong et al., 2005]. Sensor 
design is an important aspect for the mentioned measurements, such as for differentiation of stem cells and differentiated cells [Dalmay et al., 2009]. A recent summary of single cell dielectric measurements is given by Sun and Morgan [Sun and Morgan, 2010]. DS has also been proposed to detect living organisms in extreme environments such as Martian soil [Miller and Warmflash, 2011].

Virus detection is a serious issue in the biopharmaceutical industry. DS can be useful for cultivation of virus producing cell lines [Bragos et al., 2006]. The detection of small virus concentrations (down to a $\mathrm{MOI}$ of 0.0006 ) of herpes simplex infecting Vero cells (green monkey kidney) is possible using a specially designed electrode based chip and DS. The state of infection was clearly reflected by the impedance signal and spectra correlated to cell/cell or cell/substrate junctions, determined by off-line methods. Furthermore, a correlation to different MOI was detected [Bragos et al., 2006].

In summary, the field of DS of cell cultures is rapidly expanding. Increasingly sophisticated information related to cells in a whole culture down to individual cells is being extracted from the DS signals.

\subsubsection{DS Applications in Production Processes}

-Several examples of the application of DS in biopharmaceutical production processes have been reported in the literature. While many and sometimes unknown parameters may impact a cell culture some of the main issues are the cell concentration, cell death, due to shear, toxic chemicals, virus infection, changes in cell size and metabolism, osmotic stress, and immobilization processes of adherent growing cells. It will be shown below that all of these main issues can be successfully monitored by DS.

There are certainly limitations of DS in cell culture. Insertion of DS electrodes into a hollow fiber module for example did not lead to reliable results [Blute et al., 1988]. Cultures where cells grow either in suspension or on solid carriers in relatively conventional vessels such as stainless steel reactors or disposable systems are the focus here.

\subsubsection{Examples of Mammalian Cell Cultures}

Noll et al. [Noll and Biselli, 1998] describe the use of DS to monitor suspended and immobilized hybridoma cells in a fluidized bed reactor. DS together with Schwan's equations [Pethig and Kell, 1987] allowed the development of correlations of the capacitance to derive the membrane area, changes in cell physiology, cell size, apoptosis, monitoring of nucleotide triphosphates and ATP, cellular protein content, and the glutamine consumption rate. For the immobilized cells, the progress of immobilization could be monitored, as the measured capacitance increased proportional to the progress of cell immobilization. Immobilized cells change their size according to reduced available carrier surface as the cell density increases, but on the other hand, the increased immobilized cell density compared to suspended cells improves the signal to noise ratio. For the immobilized cell culture, the comparison of the cell density and the capacitance during the fermentation showed deviations, which result from a drastic decrease in the cell specific capacitance, $\mathrm{C}_{\mathrm{s}}$. Further results indicated that changes in the cell physiology during a batch culture are reflected in the measured capacitance. An excellent correlation between the specific capacitance and the specific amount of nucleotide triphosphates in the cells could be shown. It was also shown that during a batch culture, the cell specific capacitance signal changes by about $45 \%$, having a maximum value at the maximum growth rate [Noll and Biselli, 1998].

Similar correlations were found for $\mathrm{CHO}$ cells in a perfusion culture [Cannizzaro et al., 2003]. Monitoring of batch and fed-batch processes of $\mathrm{CHO}$ cells with DS has been recently reported. [Opel and Amanullah, 2010]. Linear modeling, Cole-Cole modeling, and partial least squares regression were used to correlate the DS data with routine biomass measurements of viable packed cell volume, viable cell concentration, cell size, and the oxygen uptake rate. Excellent correlations were found during the growth phase, but the stationary and declining phases showed weakened correlations which could not be improved when taking the changing cell radius in account. Examination of the correlation between permittivity, oxygen uptake rate, and viable cell concentration showed how critical the definition of viability is when analyzing biomass online. Furthermore, values of critical frequency, $\alpha$ 
(cole-cole parameter) and dielectric parameters of static internal conductivity and membrane capacitance per area were calculated. As these values did not remain constant throughout the process, important information for correlations was gained. Conclusions included that the common assumption of constant size and dielectric properties used are not always valid during later phases of cell cultures processes. Dielectric spectroscopy was found not to be a surrogate for viable cell concentration, but rather a measurement of viable biomass, providing information on the physiological state of a culture [Opel and Amanullah, 2008].

DS applied to fed-batch $\mathrm{CHO}$ expansion processes with two different cell lines has been reported [Ansorge et al., 2007]. Nutrient availability was monitored by the critical frequency and the online dual frequency permittivity signal. Feeding resulted in a sudden increase in permittivity and critical frequency and a corresponding decline was reported when nutrient depletion occurred. When the cell radius remained constant, a good correlation between the oxygen uptake rate and the critical frequency was found, indicating that metabolic activity is reflected in the critical frequency. When changes in cell size were monitored, data were difficult to interpret. The authors hypothesize that multi-frequency measurements can give information on the intracellular or physiological state of the cells, allowing to optimize and better understand feed strategies. This was confirmed for other cell lines and systems [Ansorge et al., 2007]. In 2010, similar results were published for a batch process of $\mathrm{CHO}$ cells on the laboratory and pilot scale [Ansorge et al., 2010].

DS measurements of adherent growing Vero cells producing rabies virus in a stirred tank reactor on Cytodex 1 carrier were recently described [Rourou et al., 2010]. Batch cultures, perfused cultures, and cultures in animal component free media showed a linear relationship between the permittivity and the viable cell density measurements during the growth phase as well as for the virus production phase. Calculations of the critical frequency allowed monitoring of cell lysis. Changes in the membrane capacitance and intracellular conductivity where monitored through changes in the critical frequency.

Applications of RFI measurements for mammalian cell cultivation have been reviewed [Carvell and Dowd, 2006]. Table 1 shows a summary of available literature based on the literature cited here and in Carvell and Dowd's paper.

Monitoring of cell death by DS has been reviewed [Patel and Markx, 2008]. Cell death is often associated with a loss of the integrity of the cell membrane or a change in membrane permeability. This can be monitored by DS, as capacitance values decrease and membrane conductance increases [Hoeber, 1910]. Scientists ascribe an increase in the capacitance to cell shrinking and membrane smoothing with discussion still ongoing. Several types of cell death are described. In the case of apoptosis, smoothing of the membrane occurs, cells shrink, and are becoming spherical. The cytoplasm condenses and finally the cells lyse and break down into vesicles. This phenomenon was monitored by large changes in the cell's dielectric properties in HL60 and Jurkat cells. The effects of osmotic stress, shear and other mechanical stress, infection of cells by viruses, and the toxic effects of solvents intercalating the membranes have all been related to changes in the dielectric spectra.

\subsubsection{Examples of Insect Cell Cultures}

Insect cell cultures are widely used in the production of recombinant proteins for a variety of different purposes utilizing the Baculovirus Expression Vector System (BEVS). Reports of DS as an on-line monitoring tool for insect cell cultures are relatively scarce.

Zeiser et al. [Zeiser et al., 1999] appear to be the first to report capacitance measurements for cell cultures of uninfected and infected Spodoptera frugiperda (Sf-9) insect cells. The relative permittivity correlated well with the viable cell density for uninfected cells and a culture infected with a baculovirus encoding for $\beta$-galactosidase ( $\mathrm{MOI} 10$ ). As signals showed a further increase of permittivity after infection, it was shown to be possible to monitor a synchronous infection (with high $\mathrm{MOI}$ and arrested cell division). This was mainly thought to be due to a significant increase in cell diameter after infection. Interestingly, a plateau in the permittivity signal was observed 18-24h post-infection, which could be correlated to a temporary cell size leveling during this time. Beyond post infection, the 
following cell lysis could be detected, as the signal decreased due to a decrease in cell concentration and size. Parallel to a further signal decrease due to cell size reduction, the highest $\beta$-galactosidase titer could be detected.

The same group as above reported in 2000 on monitoring of high cell density fed batch cultures, where the infection strategy was of special interest. Uninfected and infected Sf-9 cells [Elias et al., 2000] were cultivated and correlations of impedance signals with physiological parameters during growth and infection of two different insect cell cultures (Sf-9, High-5) [Zeiser et al., 2000] were made. During the cultivation of the Sf-9 cells, a signal plateau was detected, which corresponded to a peak in the $\mathrm{CO}_{2}$ evolution rate and the release of virus particles into the medium. Infection at a lower $\mathrm{MOI}$ of 0.001 did not result in a cell division arrest at the time of infection and $\mathrm{CO}_{2}$ evolution rates were delayed compared to the results obtained for infections at higher MOI values. In addition, infection of another insect cell line (High-5), ( $\mathrm{MOI} 10$ ) generally matched the results in Sf-9 cell cultures. The authors concluded that both $\mathrm{CO}_{2}$ evolution rate and relative permittivity can be used to directly measure the physiological state of the cells during the entire process and suggest that the relative permittivity measurement could be used to optimize or detect the time of harvest reliably. This is especially important for products requiring post-translational modifications.

DS applied to Sf-9 insect cell cultures has been reported more recently [Ansorge et al., 2007]. Off-line biovolume measurements correlated well with the permittivity signal of DS measurements for a limited time after infection. Only off-line analysis of the viable biovolume (by Vi-CELL) and the total biovolume (by CASY 1) correlated well with the permittivity measurement throughout the entire time the culture was tracked. Multiple frequencies over the range of $300 \mathrm{kHz}$ to $10 \mathrm{MHz}$ were observed by DS to obtain the $\beta$-dispersion and its characteristic values. It was found that the characteristic frequency changes during the culture correlated with changing cell diameter but changes in cell membrane properties are suspected to also have an influence on this parameter.

A large-scale production process for recombinant adeno-associated vectors (rAAV) using the BEVS system in Sf-9 cells was reported to have been monitored and optimized using DS [Negrete et al., 2007]. They compared the profiles obtained at different frequencies and used the relative permittivity measurement to determine the optimum time of harvest. In this case a second local maximum in the permittivity profile could be observed at about $48 \mathrm{~h}$ post-infection, which correlated to the maximum product yield.

\section{Summary and Outlook}

DS appears to be a promising non-invasive on-line tool for the monitoring of cell cultures, in research as well as for production processes. The potential to follow cell concentration, cell size, metabolic state, cell morphology, apoptosis, immobilization, viral infection, and virus release as well as a number of other parameters in real-time gives important information and enables improved process understanding, process control, and optimization while satisfying PAT requirements. Not only suspension cultures but also adherent growing cell lines have been successfully monitored, opening new possibilities for process monitoring in this area. In comparison to other common methods, the DS allows in-line process monitoring and control, probes can be sterilized in-situ, and are available as disposable units. The technique may be less susceptible to particles or fouling effects than optical turbidity measurements and is an ideal candidate as a tool for process automation in biopharmaceutical production processes.

Some areas of DS in cell culture monitoring and optimization can likely be addressed through further development. Possible approaches are outlined here according to the literature and the author's own experience. The changes in cell size during cultivation and/or infection impact the ideal critical frequency $f_{c}$. This might be addressed through continuous frequency scans. 
Both components in the solution besides the cells to be monitored, and changes in simple nonbiological parameters impact DS. The optimum measurement frequency has to be calibrated by frequency scans of cell-free and cell-containing solutions of different conductivity [Noll and Biselli, 1998]. Since the temperature greatly influences the dielectric behavior of cells and cell suspensions, temperature should be kept constant or temperature correction is required, which leads to a significant reduction of the thermal contribution to experimental noise [Asami et al., 1999]. Solid particles can cause a significant displacement of cell-containing solution, which may reduce the measured capacitance. This may require separate calibration measurements.

A fundamental issue is the assumption of spherical cells which simplifies the mathematical treatment. Non-spherical cells, cell protrusions, or cell deformation could probably be included in the mathematical description if independent information is available on these subtle geometric issues to essentially calibrate the DS measurement [Zeiser et al., 1999, Zeiser, et al., 2000]. However, the measurements made to provide a reference for DS measurements are often not without ambiguities either.

Organisms or cells that contain organelles such as mitochondria or other membrane structures can impact the DS signal through internal events rather than the external membranes [Noll and Biselli, 1998].

The capabilities and the potential of DS seem to outweigh the disadvantages especially for industrial applications. The relative simplicity and ruggedness of the probe is a significant advantage. DS can improve process stability, product quality and cost reduction for biopharmaceuticals. The growing area of regenerative medicine including cell therapy and gene therapy with examples such as production of encapsulated mesenchymal stem cells could be considered a good application for DS. , Controlled cell expansion is often required for mesenchymal stem cell production [Weber et al., 2008, Weber, et al., 2007a, Weber, et al., 2007b]. In-line monitoring by DS for cell density and the time for culture harvest might be especially useful when stem cells are grown adherent or on carriers in fixed bed reactors since it is difficult to take samples.

DS may also be useful in more fundamental aspects such as research on the differentiation of stem cells. Structural information can be obtained using integrated electrodes allowing the monitoring of growth and differentiation [Bragos et al., 2006].

In medicine, viruses can serve to prepare vaccines, but are also an element of gene therapy [Alexander et al., 2007, Edelstein, et al., 2007, Stanbridge, et al., 2003]. These viruses are mainly produced in mammalian packaging cell lines [Merten, 2004] or in insect cell lines using baculovirus [Negrete et al., 2007, Stanbridge et al., 2003]. The same cell culture system can be used to produce recombinant proteins for vaccines. The application of DS may be suitable for monitoring of these production processes [Nehring et al., 2006], allowing process control under PAT and GMP [Negrete et al., 2007]. The infection process of cells can be monitored directly by DS.

DS has been shown to be a useful and in some respects advantageous asset for cell culture. Applications range from the fundamental to process optimization and control. The ability to derive rather sophisticated information on a cell culture without the danger of breeching sterility or the time delays of more conventional measurements is a significant advantage. The ruggedness of the needed probes, along with availability of systems and probes ranging from sterilizable probes for standard ports to probes for disposable bags from reputable suppliers allows integration in processes even under strict regulatory requirements. It seems likely that DS technology will further grow in importance for cell culture applications. 


\section{Acknowledgement}

We would like to thank the Hessian State Ministry of Higher Education, Research and the Arts for the financial support within the Hessen initiative for scientific and economic excellence (LOEWEProgram). The authors would also like to thank the Federal Ministry of Economics and Technology of Germany (KF2268901UL9), and Boehringer Ingelheim Vetmedica, Inc. for financial support.

\section{References}

Aber Instruments, Viable Biomass Probes for Disposable Bioreactors. Press Release February 2008 [cited 15.12.2009]; Available from: http://www.aber-instruments.co.uk.

Alexander BL, Ali RR, Alton EW et al., Progress and prospects: gene therapy clinical trials (part 1). Gene therapy, 2007; 14(20): 1439.

Ansorge S, Esteban G, Schmid G, On-line monitoring of infected Sf-9 insect cell cultures by scanning permittivity measurements and comparison with off-line biovolume measurements. Cytotechnology, 2007; 55(2-3): 115-24.

Ansorge S, Esteban G, and Schmid G, Multifrequency permittivity measurements enable on line monitoring of changes in intracellular conductivity due to nutrient limitations during batch cultivations of $\mathrm{CHO}$ cells. Biotechnology progress, 2010; 26(1): 272-283.

Arnold WM, Monitoring of biological cell collection by dielectric spectroscopy. Annular Report Conference on Electrical Insulation and Dielectric Phenomena 2001 [cited 15.12.2009]; Available from: http://ieeexplore.ieee.org/stamp/stamp.jsp?arnumber=00963484.

Asami K, Gheorghiu E, Yonezawa T, Real-time monitoring of yeast cell division by dielectric spectroscopy. Biophysical journal, 1999; 76(6): 3345-3348.

Austin GD, Watson RWJ, D' Amore T, Studies of online viable yeast biomass with a capacitance biomass monitor, Fermentation and Bioindustrial Chemistry, 1994; 43(4):337-341.

Baldi L, Hacker DL, Adam M et al., Recombinant protein production by large-scale transient gene expression in mammalian cells: state of the art and future perspectives. Biotechnol Lett, 2007; 29(5): 677-84.

Barsoukov E, Macdonald JR. Impedance spectroscopy: theory, experiment, and applications, WileyInterscience, 2005.

Blute T, Gillies R, Dale BE, Cell density measurements in hollow fiber bioreactors. Biotechnol Prog, 1988; 4: 202-209.

Boudreau M, Benton T, Bioprocess Control: What the Next 15 Years Will Bring. 2008 14.12.2009 [cited 15.12.2009]; Available from: http://www.emersonprocess.com/.

Bragos R, Sarro E, Fontova A et al., Four versus two-electrode measurement strategies for cell growing and differentiation monitoring using electrical impedance spectroscopy. Conf Proc IEEE Eng Med Biol Soc, 2006; 1: 2106-9.

Butler M, Animal cell cultures: recent achievements and perspectives in the production of biopharmaceuticals. Appl Microbiol Biotechnol, 2005; 68(3): 283-91.

Cannizzaro C, Gugerli R, Marison I et al., On-line biomass monitoring of $\mathrm{CHO}$ perfusion culture with scanning dielectric spectroscopy. Biotechnol Bioeng, 2003; 84(5): 597-610.

Carvell JP, Viable Biomass Sensor for Bioreactors, in BIOforum Europe. 2008: Darmstadt, Germany. p. 54-55.

Carvell JP, Dowd JE, On-line Measurements and Control of Viable Cell Density in Cell Culture Manufacturing Processes using Radio-frequency Impedance. Cytotechnology, 2006; 50(1-3): 35-48.

Cerckel I, Garcia A, Degouys V et al., Dielectric spectroscopy of mammalian cells. 1. Evaluation of the biomass of HeLa- and $\mathrm{CHO}$ cells in suspension by low-frequency dielectric spectroscopy. Cytotechnology, 1993; 13(3): 185-193.

Ceriotti L, Ponti J, Broggi $\mathrm{F}$ et al., Real-time assessment of cytotoxicity by impedance measurement on a 96-well plate. Sensors and Actuators B., 2007a; 123: 769-778. 
Ceriotti L, Ponti J, Colpo P et al., Assessment of cytotoxicity by impedance spectroscopy. Biosens Bioelectron, 2007b; 22(12): 3057-63.

Chew W, Sharratt P, Trends in process analytical technology. Analytical Methods,2010; 2(10): 14121438.

Clementschitsch F, Bayer K, Improvement of bioprocess monitoring: development of novel concepts. Microb Cell Fact, 2006; 5: 19.

Cook JA, Mitchell JB, Viability measurements in mammalian cell systems. Anal Biochem, 1989; 179(1): $1-7$.

Coster HGL, Chilcott TC, and Coster ACF, Impedance spectroscopy of interfaces, membranes and ultrastructures. Bioelectrochemistry and Bioenergetics, 1996; 40(2): 79-98.

Czermak P, Pörtner R, Brix A, Special Engineering Aspects, in Cell and Tissue Reaction Engineering, Editors: R Eibl, D Eibl, R Pörtner et al., 2009; Springer-Verlag Berlin Heidelberg. p. 83-172.

Dalmay C, Cheray M, Pothier A et al., Ultra Sensitive Biosensor Based on Impedance Spectroscopy at Microwave Frequencies for Cell Scale Analysis. Sensors and Actuators A: Physical, 2009; 1(1): 742-745.

Daniell H, Streatfield SJ, Wycoff K, Medical molecular farming: production of antibodies, biopharmaceuticals and edible vaccines in plants. Trends Plant Sci, 2001; 6(5): 219-26.

Davey Cl, Davey HM, Kell DB et al., Introduction to the dielectric estimation of cellular biomass in real time, with special emphasis on measurements at high volume fractions. Analytica chimica acta, 1993a; 279(1): 155-161.

Davey Cl, Guan Y, Kemp RB et al., Real-time monitoring of the biomass content of animal cell cultures using dielectric spectroscopy. in Section Title: Fermentation and Bioindustrial Chemistry. 1997.

Davey $\mathrm{Cl}$, Markx $\mathrm{GH}$, and Kell DB, On the dielectric method of monitoring cellular viability. Pure \& Appl. Chem., 1993b; 65(9): 1921-1926.

De Beer TR, Baeyens WR, Ouyang $\mathrm{J}$ et al., Raman spectroscopy as a process analytical technology tool for the understanding and the quantitative in-line monitoring of the homogenization process of a pharmaceutical suspension. Analyst, 2006; 131(10): 1137-44.

Degouys V, Cerckel I, Garcia A et al., Dielectric spectroscopy of mammalian cells. 2. Simultaneous in situ evaluation by aperture impedance pulse spectroscopy and low frequency dielectric spectroscopy of the biomass of HTC cells on Cytodex 3. Cytotechnology, 1993; 13(3): 195202.

Doerner S, Dielektrische und akustische Spektroskopie als prozesstaugliche Analyseverfahren zur Charakterisierung fluid-disperser Systeme, in Faculty of Electrical Engineering and Information Technology. 2008; Otto-von-Guericke-Universität Magdeburg: Magdeburg. p. 188.

Douennebier G, Tups, H., FDA PAT Initiative - Eine Anwendersicht zu technischen Möglichkeiten und aktueller industrieller Umsetzung. Chemie Ingenieur Technik, 2007; 79(12): 2019-2028.

Dowd JE, Jubb A, Kwok KE et al., Optimization and control of perfusion cultures using a viable cell probe and cell specific perfusion rates. Section Title: Fermentation and Bioindustrial Chemistry, 2003; 42(1): 35-45.

Ducommun $\mathrm{P}$, Bolzonella I, Rhiel $\mathrm{M}$ et al., On-line determination of animal cell concentration. Biotechnology and Bioengineering, 2001; 72(5): 515-22.

Ducommun $\mathrm{P}$, Kadouri A, von Stockar $\mathrm{U}$ et al., On-line determination of animal cell concentration in two industrial high-density culture processes by dielectric spectroscopy. Biotechnol Bioeng, 2002a; 77(3): 316-23.

Ducommun P, Rueux PA, Kadouri A et al., Monitoring of temperature effects on animal cell metabolism in a packed bed process. Section Title: Fermentation and Bioindustrial Chemistry, 2002b; 77(7): 838-842.

Dziong D, Kearney RE, Tabrizian $\mathrm{M}$ et al., A Highly Responsive System for On-line in vitro Assessment of Tissue Growth within MicroPorous Polymer Scaffolds. Conf Proc IEEE Eng Med Biol Soc, 2005; 1: 1043-6.

Edelstein ML, Abedi MR, and Wixon J, Gene therapy clinical trials worldwide to 2007-an update. The Journal of Gene Medicine, 2007; 9(10): 833-42. 
Ehret $\mathrm{R}$, Baumann $\mathrm{W}$, Brischwein $\mathrm{M}$ et al., Monitoring of cellular behaviour by impedance measurements on interdigitated electrode structures. Biosens Bioelectron, 1997; 12(1): 29-41.

Ehret R, Baumann W, Brischwein M et al., On-line control of cellular adhesion with impedance measurements using interdigitated electrode structures. Med Biol Eng Comput, 1998; 36(3): $365-70$

Elias CB, Zeiser A, Bedard C et al., Enhanced growth of Sf-9 cells to a maximum density of 5.2 A107 cells per $\mathrm{mL}$ and production of $\hat{i}^{2}$-galactosidase at high cell density by fed batch culture. Section Title: Fermentation and Bioindustrial Chemistry, 2000; 68(4): 381-388.

Esteban G, Ansorge S, Schmid G. On-line viable cell density and physiological states monitoring by dielectric spectroscopy Sf9 growth and infection process. 21.01.2009 [cited 14.12.2009]; Available from: www.fogale.com/Biomass.

Esteban G, Luong B, Ossart F, On-line and in situ counting of cells in a biological culture medium based on dielectric and conductance measurements with several frequencies, in Section Title: Biochemical Methods. 2008: Fr.: Patent Application Country: Application: US; Patent Country: US; Priority Application Country: FR. p. 13.

FDA. Guidance for Industry PAT- A framework for innovative pharmaceutical manufacturing and quality assurance. 2004 [cited 19.02.2009]; Available from: http://www.fda.gov/cder/OPS/PAT.htm.

Fehrenbach R, Comberbach M, Petre JO, On-line biomass monitoring by capacitance measurement. J Biotechnol, 1992; 23(3): 303-14.

Folly ROM, Valdman B, Potentiomatric sensor for on line glucose determination. Biotechnolgy Techniques, 1996; 10(11): 867-870.

Gnoth S, Jenzsch M, Simutis R et al., Process Analytical Technology (PAT): batch-to-batch reproducibility of fermentation processes by robust process operational design and control. J Biotechnol, 2007; 132(2): 180-6.

Guan Y, Evans PM, Kemp RB, Specific heat flow rate: an online monitor and potential control variable of specific metabolic rate in animal cell culture that combines microcalorimetry with dielectric spectroscopy. Section Title: Biochemical Methods, 1998; 58(5): 464-477.

Guan Y, Kemp RB. The viable cell monitor: a dielectric spectroscope for growth and metabolic studies of animal cells on macroporous beads. in Section Title: Biochemical Methods. 1997.

Guo M, Chen J, Yun X et al., Monitoring of cell growth and assessment of cytotoxicity using electrochemical impedance spectroscopy. Biochim Biophys Acta, 2006; 1760(3): 432-9.

Heubach JF, Graf EM, Leutheuser J et al., Electrophysiological properties of human mesenchymal stem cells. The Journal of physiology, 2004; 554(3): 659-672.

Hildebrandt $\mathrm{C}$, Büth $\mathrm{H}, \mathrm{Cho} \mathrm{S}$, Detection of the osteogenic differentiation of mesenchymal stem cells in 2D and 3D cultures by electrochemical impedance spectroscopy. Journal of biotechnology, 2010; 148(1): 83-90.

Hoeber R, Eine Methode die elektrische Leitfähigkeit im Innern von Zellen zu messen. Arch. Ges. Physiol., 1910; 133: 237-259.

Huang X, Greve DW, Nguyen DD et al. Impedance based biosensor array for monitoring mammalian cell behavior. in Sensors 2003, Proceedings of IEEE. 2003.

Huang YL, Li SY, Dremel BAA et al., On-line determination of glucose concentration throughout animal cell cultures based on chemiluminescent detection of hydrogen peroxide coupled with flow-injection analysis. Journal of biotechnology, 1991; 18(1-2): 161-172.

Kourti T, The Process Analytical Technology initiative and multivariate process analysis, monitoring and control. Anal Bioanal Chem, 2006; 384(5): 1043-8.

Kussow CM, Zhou W, Gryte DM et al., Monitoring of mammalian cell growth and virus production process using on-line oxygen uptake rate measurement. Enzyme and Microbial Technology, 1995; 17(9): 779-783.

Lee RM, Choi H, Shin JS et al., Distinguishing between apoptosis and necrosis using a capacitance sensor. Biosensors and Bioelectronics, 2009; 24(8): 2586-2591.

Li F, Hashimura Y, Pendleton R et al., A systematic approach for scale-down model development and characterization of commercial cell culture processes. Biotechnol Prog, 2006; 22(3): 696-703. 
Liu Q, Yu J, Xiao L et al., Impedance studies of bio-behavior and chemosensitivity of cancer cells by micro-electrode arrays. Biosensors and Bioelectronics, 2009; 24(5): 1305-1310.

Male KB, Gartu PO, Kamen AA et al., On-line monitoring of glucose in mammalian cell culture using a flow injection analysis (FIA) mediated biosensor. Biotechnol Bioeng, 1997; 55(3): 497-504.

Mansfeld F. Electrochemical impedance spectroscopy, Corrosion and Environmental Effects Labs, Dept. of Materials Science and Engineering, University of Southern California, Los Angeles, CA, USA. Editor(s): Marcus, Philippe; Mansfeld, Florian. Analytical Methods in Corrosion Science and Engineering, 2006: 463-505.

Malleo D, Nevill JT, Lee LP et al., Continuous differential impedance spectroscopy of single cells. Microfluidics and Nanofluidics, 2009: 1-8.

Marszalek P, Liu DS, Tsong TY, Schwan equation and transmembrane potential induced by alternating electric field. Biophysical Journal, 1990; 58(4): 1053-1058.

Merten OW, State-of-the-art of the production of retroviral vectors. The Journal of Gene Medicine, 2004; 6: 105-124.

Miller JH, Warmflash D, Martian Soil Biosensors Based on Dielectric Spectroscopy, Institute for Space Systems Operations Annual Report, 2006, p. 21-26, available at http://www.isso.uh.edu/publications/ A2006/2006_021_miller.pdf, retrieved February 2011]

Myers MA, Direct measurement of cell numbers in microtitre plate cultures using the fluorescent dye SYBR green I. J Immunol Methods, 1998; 212(1): 99-103.

Nacke $T$, Land R, Barthel A et al. Process instrumentation for impedance spectroscopy-a modular concept. 2008.

Negrete A, Esteban G, Kotin RM, Process optimization of large-scale production of recombinant adeno-associated vectors using dielectric spectroscopy. Section Title: Fermentation and Bioindustrial Chemistry, 2007; 76(4): 761-772.

Negrete A, Kotin RM, Large-scale production of recombinant adeno-associated viral vectors. Section Title: Biochemical Genetics, 2008; 433: 79-95.

Nehring D, Gonzalez R, Pörtner R et al., Experimental and modelling study of different process modes for retroviral production in a fixed bed reactor. Journal of biotechnology, 2006; 122(2): 239253.

Noll T, Biselli M, Dielectric spectroscopy in the cultivation of suspended and immobilized hybridoma cells. J Biotechnol, 1998; 63(3): 187-98.

Opel CF, Li J, Amanullah A, Quantitative modeling of viable cell density, cell size, intracellular conductivity, and membrane capacitance in batch and fed-batch $\mathrm{CHO}$ processes using dielectric spectroscopy. Biotechnology Progress, 2010; 26: 1187-1199.

Patel P, Markx GH, Dielectric measurement of cell death. Enzyme and microbial technology, 2008; 43: 463-470.

Pethig R, Kell DB, The passive electrical properties of biological systems: their significance in physiology, biophysics and biotechnology. Phys Med Biol, 1987; 32(8): 933-70.

Pickup JC, Hussain F, Evans ND et al., Fluorescence-based glucose sensors. Biosens Bioelectron, 2005; 20(12): 2555-65.

Qiu Y, Liao R, Zhang X, Impedance-Based Monitoring of Ongoing Cardiomyocyte Death Induced by Tumor Necrosis Factor-[alpha]. Biophysical journal, 2009; 96(5): 1985-1991.

Qui Y, Lioa R, Zhang X, Real-time Monitoring Primary Cardiomyocyte Adhesion Based on Electrochemical Impedance Spectroscopy and Electrical Cell-Substrate Impedance Sensing. Anal. Chem., 2008; 80: 990-996.

Rahman ARA, Register J, Vuppala $\mathrm{G}$ et al., Cell culture monitoring by impedance mapping using a multielectrode scanning impedance spectroscopy system (CellMap). Physiological Measurement, 2008; 29(6): 227.

Rathore AS, Yu M, Yeboah S et al., Case study and application of process analytical technology (PAT) towards bioprocessing: use of on-line high-performance liquid chromatography (HPLC) for making real-time pooling decisions for process chromatography. Biotechnol Bioeng, 2008; 100(2): 306-16.

Rengarajan K, Cristol SM, Mehta M et al., Quantifying DNA concentrations using fluorometry: a comparison of fluorophores. Mol Vis, 2002; 8: 416-21. 
Renneberg R, Lisdat F, Biosensing for the 21st Century. 2008: Springer Verlag.

Ron A, Fishelson N, Croitoriu N et al., Theoretical examination of aggregation effect on the dielectric characteristics of spherical cellular suspension. Biophysical chemistry, 2009; 140(1-3): 39-50.

Rourou S, Gaumon S, Kallel H, On-Line Monitoring of Vero Cells Cultures During the Growth and Rabies Virus Process Using Biomass Spectrometer. Cells and Culture, 2010; 4: 829-832.

Rudolph G, Brückerhoff T, Bluma A et al., Optische Inline-Messverfahren zur Zellzahl- und Zellgrößenbestimmung in der Bioprozesstechnik. Chemie Ingenieur Technik, 2007; 79(1-2): 42-51.

Sarra M, Ison AP, Lilly MD, The relationships between biomass concentration, determined by a capacitance-based probe, rheology and morphology of Saccharopolyspora erythraea cultures. Journal of Biotechnology, 1996; 51(2): 157-165.

Schmid G, Zacher D. Evaluation of a novel capacitance probe for on-line monitoring of viable cell densities in batch and fed-batch animal cell culture processes. in Section Title: Fermentation and Bioindustrial Chemistry. 2004.

Stanbridge LJ, Dussupt V, Maitland NJ, Baculoviruses as vectors for gene therapy against human prostate cancer. Journal of Biomedicine and Biotechnology, 2003; 3: 79-91.

Sun $T$, Morgan $H$, Single-cell microfluidic impedance cytometry: A review. Microfluidics and Nanofluidics, 2010; 8(4): 423-443.

Teixeira AP, Oliveira R, Alves PM et al., Advances in on-line monitoring and control of mammalian cell cultures: Supporting the PAT initiative. Biotechnology Advances, 2009; 27(6): 726-732.

Vojinovic V, Cabral JMS, Fonseca LP, Real-time-bioprocess monitoring Part I: In situ sensors. Sensors and Actuators B., 2006; 114: 1083-1091.

Walsh G, Biopharmaceutical benchmarks 2006. Nat Biotechnol, 2006; 24(7): 769-76.

Wang MH, Jang LS, A systematic investigation into the electrical properties of single HeLa cells via impedance measurements and COMSOL simulations. Biosensors and Bioelectronics, 2009; 24(9): 2830-2835.

Watkins EJ, Pfromm PH. Capacitance Spectroscopy to Characterize Organic Fouling of Electrodialysis Membranes, Journal of Membrane Science,1999; 162: 213-218

Weber C, Pohl S, Poertner R et al., Entwicklung eines Herstellungsverfahrens fuer stammzellbasierte zelltherapeutische Implantate. Chemie Ingenieur Technik, 2008; 80(9): 1286.

Weber C, Pohl S, Portner R et al., Expansion and Harvesting of hMSC-TERT. The Open Biomedical Engineering Journal, 2007a; 1(1): 38-46.

Weber C, Pohl S, Poertner R et al., Cultivation and Differentiation of Encapsulated hMSC-TERT in a Disposable Small-Scale Syringe-Like Fixed Bed Reactor. The Open Biomedical Engineering Journal, 2007b; 1: 64-70.

Wurm FM, Production of recombinant protein therapeutics in cultivated mammalian cells. Nat Biotechnol, 2004; 22(11): 1393-8.

Yu N, Atienza JM, Bernard J et al., Real-time monitoring of morphological changes in living cells by electronic cell sensor arrays: an approach to study $\mathrm{G}$ protein-coupled receptors. Anal Chem, 2006; 78(1): 35-43.

Zeiser A, Bedard C, Voyer R et al., On-line monitoring of the progress of infection in Sf-9 insect cell cultures using relative permittivity measurements. Biotechnol Bioeng, 1999; 63(1): 122-6.

Zeiser A, Elias CB, Voyer R et al., On-Line Monitoring of Physiological Parameters of Insect Cell Cultures during the Growth and Infection Process. Section Title: Fermentation and Bioindustrial Chemistry, 2000; 16(5): 803-808.

Zhuang J, Baldwin $\mathrm{WH}$, Schoenbach $\mathrm{KH}$ et al. Pulsed electric field induced changes in dielectric properties of biological cells. 2010: IEEE.

Zipper $\mathrm{H}$, Brunner $\mathrm{H}$, Bernhagen $\mathrm{J}$ et al., Investigations on DNA intercalation and surface binding by SYBR Green I, its structure determination and methodological implications. Nucleic Acids Res, 2004; 32(12): 103. 


\section{Figures}

Fig. 1 Relaxation processes tracked by $\varepsilon_{r}^{\prime}$ (permittivity of the sample in the dielectric) and $\varepsilon_{r}^{\prime \prime}$ (permittivity of the surrounding dielectric) across a spectrum of electromagnetic wave frequencies (radio frequency range RW, intermediate frequency range $M W$, infra red IR, visible light (V) and ultraviolet light (UV). Entities responding to these frequencies are schematically shown, from left to right: a living cell, a polar molecule, atomic level vibration, and electronic response. [generously provided by S. Doerner, Faculty of Electrical Engineering and Information Technology., Otto-von-Guericke-Universität Magdeburg); by permission, Mensch und Buch Verlag, Germany [Doerner, 2008].

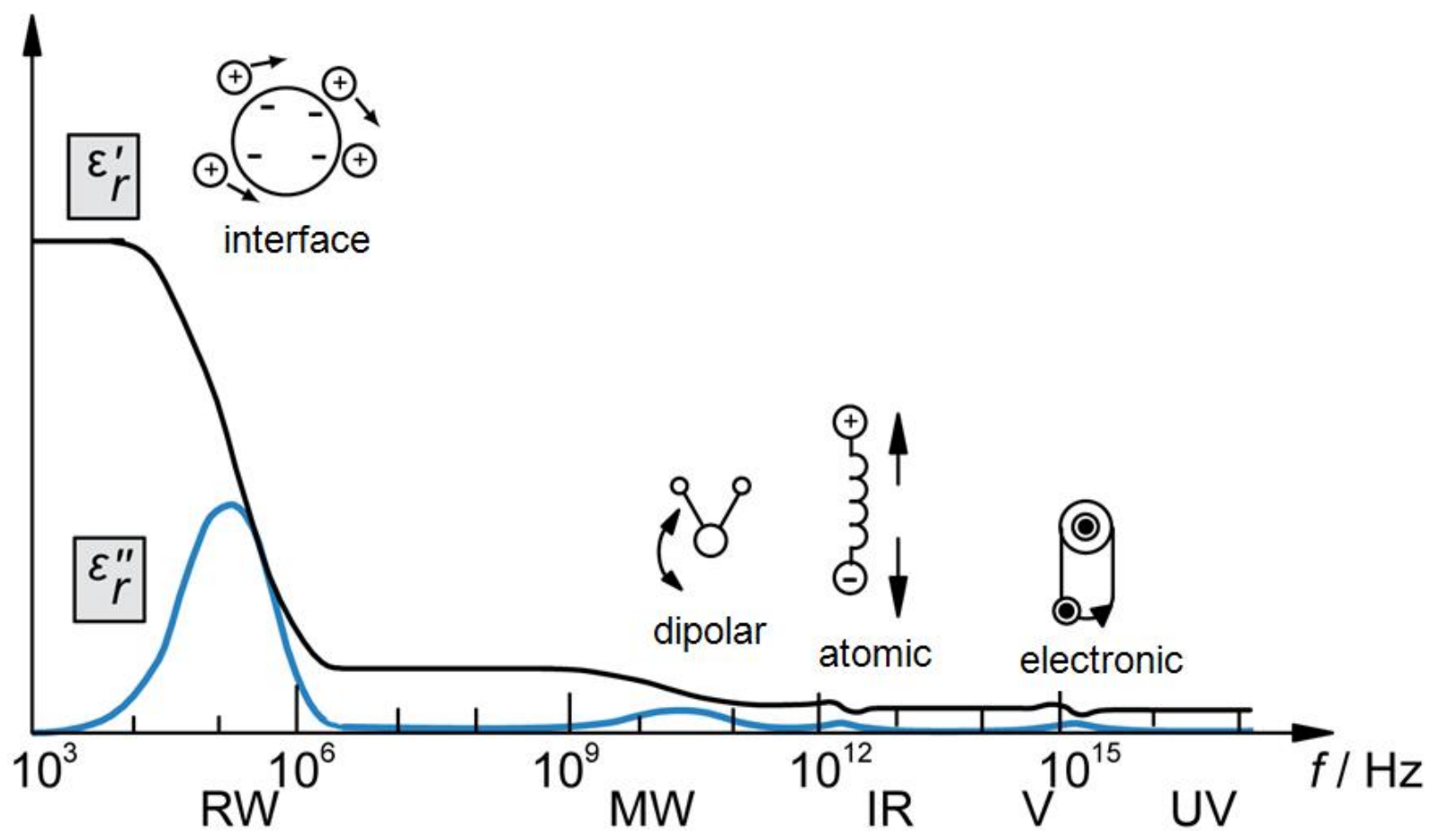


Fig. 2 Capacitance $\Delta c$, critical frequency $f_{c}$, and membrane capacitance $c_{m}$ at increasing cell densities in suspension [Cannizzaro et al., 2003]; reprinted with permission of John Wiley Sons, Inc.)

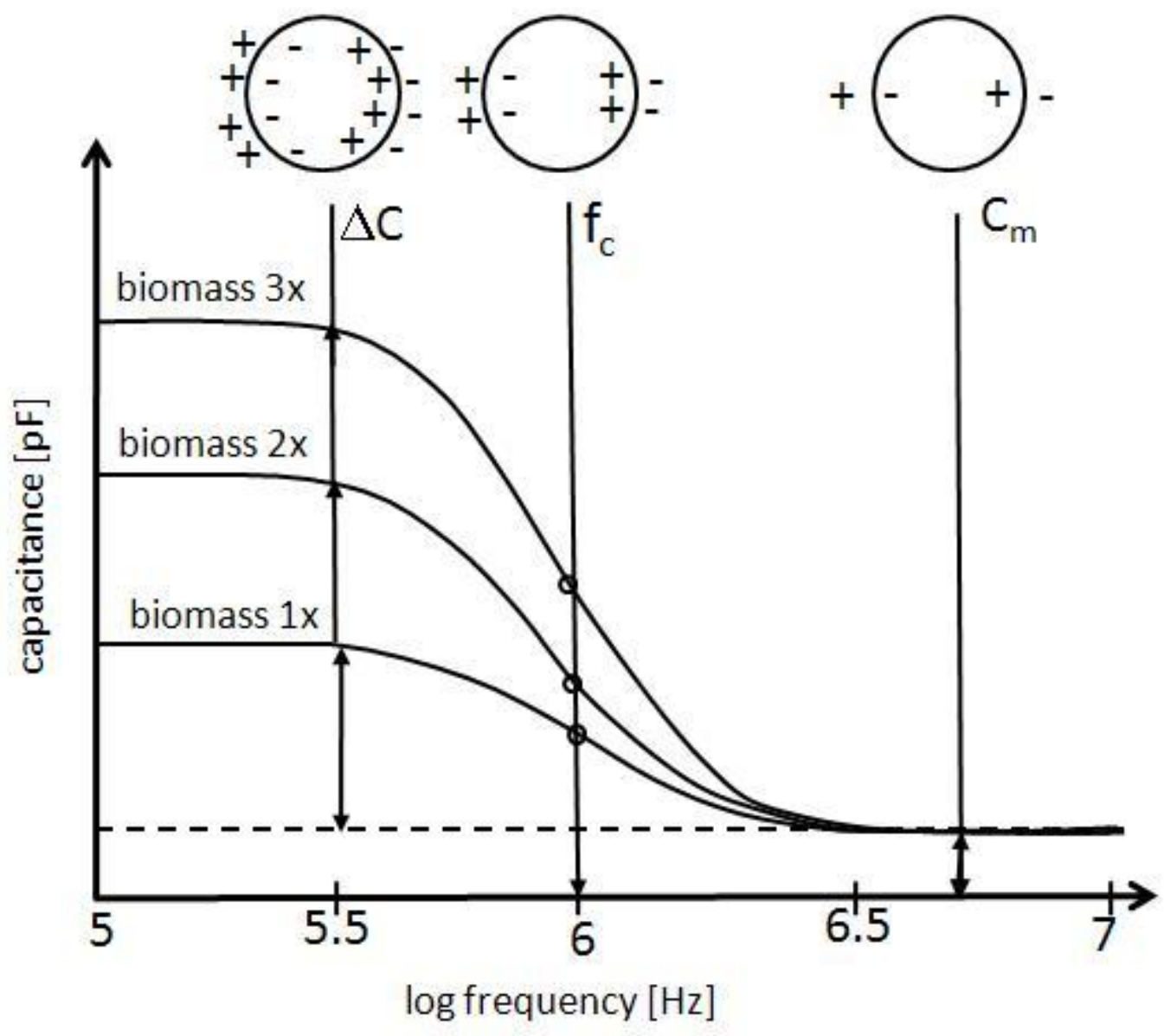


Fig. 3 Increase of the critical frequency $f_{c}$ with cell size. This graph is valid only for a remaining biovolume, even though the cell size changes. [Carvell and Dowd, 2006]; reprinted with permission of John Wiley Sons, Inc.)

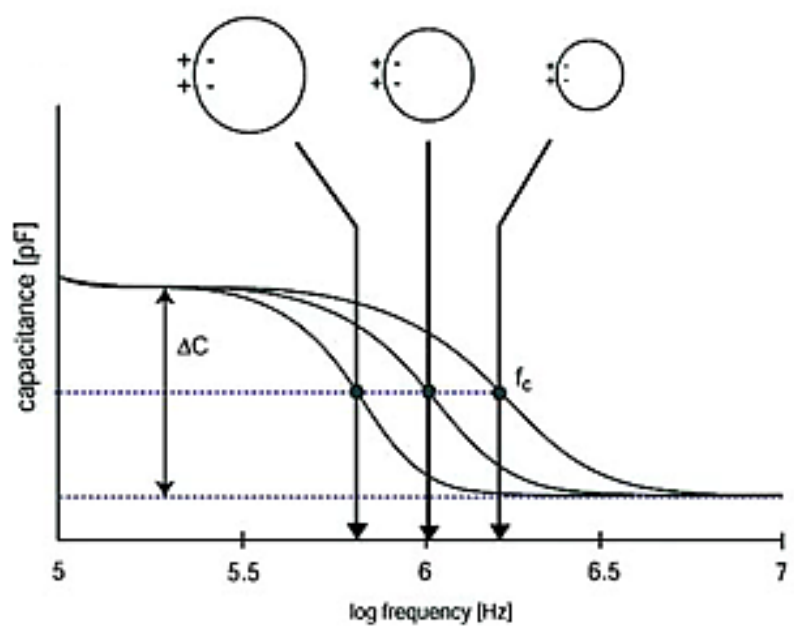

Fig. 4 FOGALE nanotech Biomass 465 with pre-amplifier and 25 and $12 \mathrm{~mm}$ reusable probes; (generously provided and with permission by R. Luemen, Cellogics GbR, Muenster, Germany).

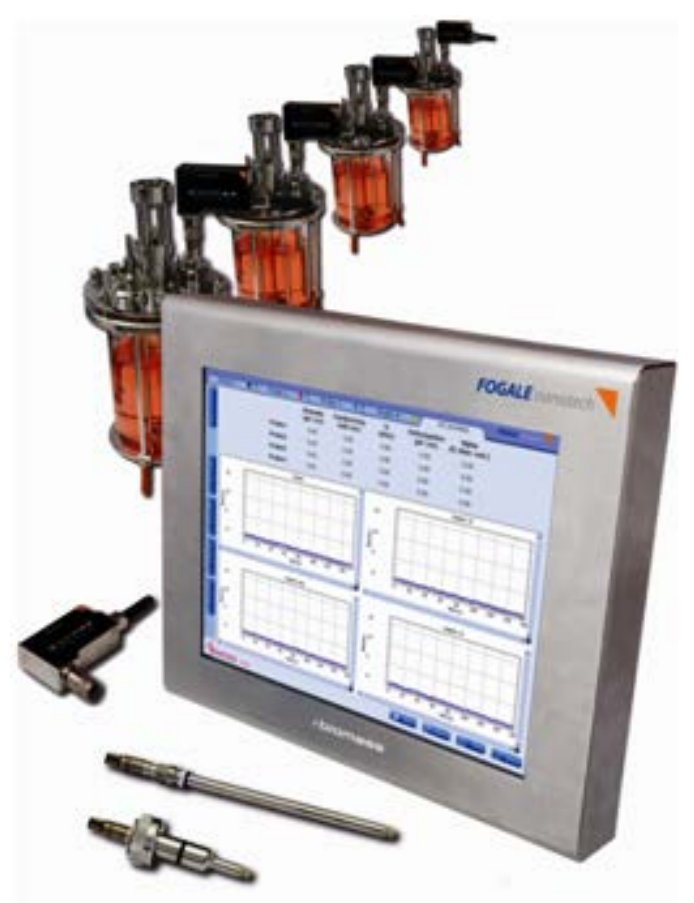


Fig. 5 Top: Aber reusable biomass probes inserted into disposable $50 \mathrm{~L}$ Hyclone bioreactor, Pall (Dreieich, Germany), Kleenpak connector; bottom left: Single use biomass probe connected to lightweight Futura (Aber product line) pre-amplifier for Biomass Monitor; bottom right: Single use biomass probe welded into 50L Hyclone SUB (Photographs courtesy of Hyclone, Logan (Utah), USA, generously provided and with permission from Carvell, J., et al.., On-line monitoring of the live cell concentration in disposable bioreactors. Aber Instruments Ltd. Science Park, Aberystwyth, Wales, UK SY23 3AH).
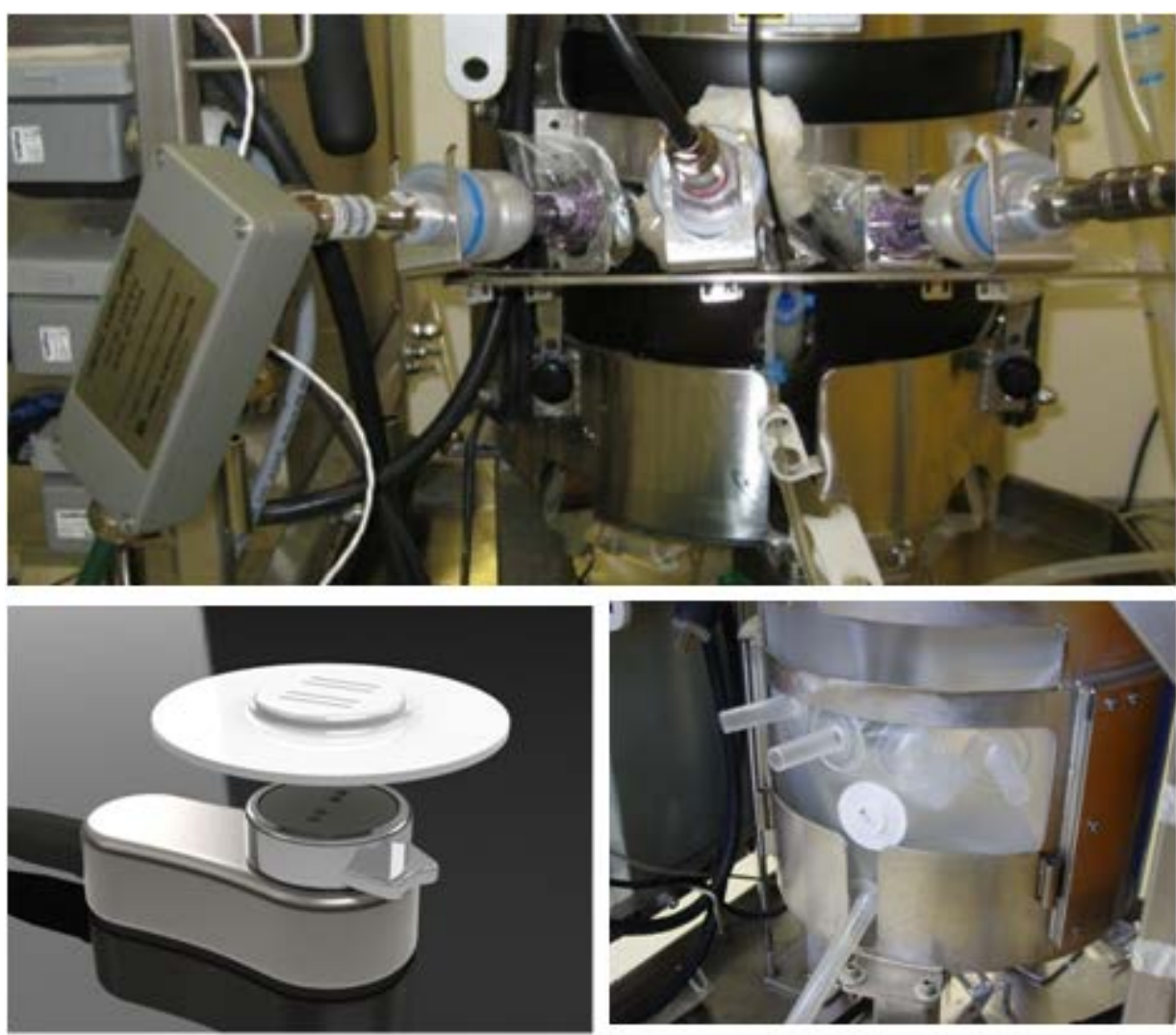

Fig. 6 FOGALE nanotech biodis series biomass sensor for single use bags; (generously provided and with permission by R. Luemen, Cellogics GbR, Muenster, Germany).

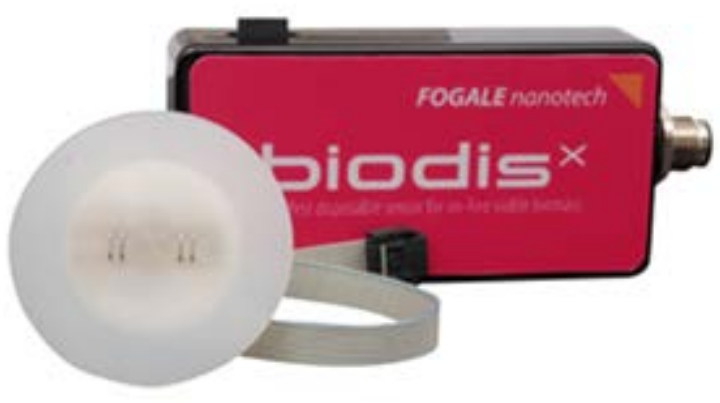




\section{Legends}

\begin{tabular}{|c|c|}
\hline Abbreviation & \\
\hline A & surface \\
\hline BEVS & Baculovirus expression vector system \\
\hline $\mathrm{BHK}$ & Baby hamster kidney \\
\hline C & Capacitance \\
\hline $\mathrm{CHO}$ & Chinese hamster ovary \\
\hline $\mathrm{CIP}$ & Cleaning in place \\
\hline$C_{M}$ & Membrane capacitance \\
\hline $\mathrm{C}_{\mathrm{S}}$ & Cell specific capacitance \\
\hline $\mathrm{d}$ & Distance \\
\hline DNA & Deoxyribonucleic acid \\
\hline DS & Dielectric Spectroscopy \\
\hline ELISA & Enzyme linked immuno sorbent assay \\
\hline EMEA & European Medicines Agency \\
\hline$f_{c}$ & Critical frequency \\
\hline FDA & Food and Drug Administration \\
\hline G & Conductance \\
\hline GMP & Good Manufacturing Practice \\
\hline HEK & Human embryo kidney \\
\hline HeLa & Henrietta Lacks \\
\hline HPLC & High pressure liquid chromatography \\
\hline $\mathrm{MOI}$ & Multiplicity of infection \\
\hline MS & Mass spectrometer \\
\hline $\mathrm{N}$ & Cell density \\
\hline NMR & Nuclear magnetic resonance \\
\hline $\mathrm{P}$ & Volume fraction \\
\hline PAT & Process Analytical Technology \\
\hline PC & Portable computer \\
\hline $\mathrm{pCO} 2$ & Carbon dioxide partial pressure \\
\hline pO2 & Oxygen partial pressure \\
\hline$r$ & Radius \\
\hline rAAV & Recombinant adeno associated vector \\
\hline RFI & Radio frequency impedance spectroscopy \\
\hline Sf-9 & Spodoptera frugiperda \\
\hline SIP & Sterilization in place \\
\hline UV-VIS & Ultra violet-visible \\
\hline$\kappa$ & Conductivity \\
\hline$\varepsilon_{0}$ & Constant permittivity in vacuum \\
\hline$\varepsilon_{\mathrm{T}}$ & Relative permittivity \\
\hline$\sigma_{\mathrm{i}}$ & Intracellular conductance \\
\hline$\epsilon_{r}^{\prime}$ & \begin{tabular}{|l}
$\begin{array}{l}\text { Permittivity of the sample immersed in the } \\
\text { dielectric (medium) }\end{array}$ \\
\end{tabular} \\
\hline$\epsilon_{\mathrm{r}}{ }^{\prime \prime}$ & Permittivity of the medium \\
\hline
\end{tabular}




\section{Tables}

Table 1 - Summarized applications of DS in cell culture

Summary of applications of DS (adapted from Carvell et al., 2006 [Carvell and Dowd, 2006] and further cited literature)

\begin{tabular}{|c|c|c|c|}
\hline Cell line & Culture conditions & Summary & Ref. \\
\hline $\mathrm{CHO}$ & $\begin{array}{l}\text { Immobilized in a } \\
\text { packed bed of } \\
\text { FibraCell discs }\end{array}$ & $\begin{array}{l}\text { DS to characterize the packed bed reactor; } \\
\text { monitoring of maximum cell concentration and } \\
\text { protein production rate; evaluation of the effect of } \\
\text { temperature on specific metabolic rates during } 3 \\
\text { months of continuous culture in a } 40 \mathrm{~L} \text { industrial } \\
\text { process; characterization of growth kinetics up to } \\
4 \times 10^{7} \text { cells } / \mathrm{mL} \text { of packed bed. }\end{array}$ & $\begin{array}{l}\text { [Ducommun } \\
\text { et al., } \\
2002 a \text {, } \\
\text { Ducommun } \\
\text { et al., } \\
2002 b]\end{array}$ \\
\hline $\mathrm{CHO}$ & Airlift reactor & $\begin{array}{l}\text { Monitoring of exponential growth and death phases, } \\
\text { and changes in the physiological state of the cells. }\end{array}$ & $\begin{array}{l}\text { [Schmid } \\
\text { and Zacher, } \\
\text { 2004] }\end{array}$ \\
\hline $\mathrm{CHO}$ & $\begin{array}{l}\text { Batch and fed-batch } \\
\text { in a stirred tank } \\
\text { reactor }\end{array}$ & $\begin{array}{l}\text { Modeling by linear, cole-cole and partial least } \\
\text { squares models with good correlations for the growth } \\
\text { phase. The assumption of constant cell size } \\
\text { throughout the process was discarded for later } \\
\text { phases of the process. }\end{array}$ & $\begin{array}{l}\text { [Opel and } \\
\text { Amanullah, } \\
\text { 2008] }\end{array}$ \\
\hline $\begin{array}{l}\mathrm{CHO} \mathrm{K} 1 / \mathrm{dhfr}^{-} \text {and } \\
\mathrm{CHO} \text { recombinant } \\
\text { for antibody } \\
\text { production }\end{array}$ & $\begin{array}{l}\text { Fed batch process in } \\
\text { a } 3 L \text { stirred tank } \\
\text { reactor }\end{array}$ & \multirow{2}{*}{$\begin{array}{l}\text { Permittivity and critical frequency allow the } \\
\text { monitoring of nutrient depletion and feed points } \\
\text { giving information on the intracellular or physiological } \\
\text { condition of the cells. Optimization and better } \\
\text { understanding of fed-batch processes. Results may } \\
\text { also be applicable for other cell lines and systems. }\end{array}$} & \multirow{2}{*}{$\begin{array}{l}\text { [Ansorge et } \\
\text { al., 2007] }\end{array}$} \\
\hline 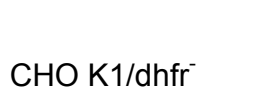 & Batch process & & \\
\hline $\mathrm{CHO} 320$ & Suspension culture & $\begin{array}{l}\text { Linear correlation between cell number and } \\
\text { capacitance; } 0.5 \mathrm{MHz} \text { optimum measurement } \\
\text { frequency. }\end{array}$ & $\begin{array}{l}\text { [Cerckel et } \\
\text { al., 1993] }\end{array}$ \\
\hline $\mathrm{CHO} 320$ & $\begin{array}{l}\text { Anchorage cells on } \\
\text { Cytopore } 1 \\
\text { microcarrier }\end{array}$ & $\begin{array}{l}\text { More accurate information than with data obtained by } \\
\text { protein content determination. }\end{array}$ & $\begin{array}{l}\text { [Guan and } \\
\text { Kemp, } \\
\text { 1997] }\end{array}$ \\
\hline $\mathrm{CHO} 320$ & $\begin{array}{l}\text { Suspension of } \\
\text { immobilized cells }\end{array}$ & $\begin{array}{l}\text { Relationship between capacitance and viable cell } \\
\text { concentration. }\end{array}$ & $\begin{array}{l}\text { [Davey et } \\
\text { al., 1997] }\end{array}$ \\
\hline $\mathrm{CHO} 320$ & $\begin{array}{l}\text { Stirred aerobic batch } \\
\text { culture }\end{array}$ & $\begin{array}{l}\text { Combination of DS with microcalorimetric } \\
\text { measurements. }\end{array}$ & $\begin{array}{l}\text { [Guan et } \\
\text { al., 1998] }\end{array}$ \\
\hline $\mathrm{CHO}$ & Perfusion culture & $\begin{array}{l}\text { Optimization and control of the system, automated } \\
\text { perfusion feeding based on live cell concentration via } \\
\text { DS data. Optimized process operation through cell } \\
\text { specific perfusion rate (based on DS) keeps the cell } \\
\text { concentration constant and optimizes recombinant } \\
\text { protein production rates. }\end{array}$ & $\begin{array}{l}\text { [Dowd et } \\
\text { al., 2003] }\end{array}$ \\
\hline HeLA & Suspension culture & $\begin{array}{l}\text { Linear correlation between cell } \\
\text { capacitance; } 0.5 \mathrm{MHz} \text { optimum } \\
\text { frequency. }\end{array}$ & $\begin{array}{l}\text { [Cerckel et } \\
\text { al., 1993] }\end{array}$ \\
\hline HTC & $\begin{array}{l}\text { Anchorage } \\
\text { dependent cells on } \\
\text { Cytodex } 5 \mathrm{~g} / \mathrm{L} \text { in } \\
\end{array}$ & $\begin{array}{l}\mathrm{DS} \text { at } 0.8 \mathrm{MHz} \text { enables accurate estimates of cellular } \\
\text { biomass from the capacitance signal. }\end{array}$ & $\begin{array}{l}\text { [Degouys et } \\
\text { al., 1993] }\end{array}$ \\
\hline
\end{tabular}




\begin{tabular}{|c|c|c|c|}
\hline & spinner flask & & \\
\hline Hybridoma & $\begin{array}{l}\text { Immobilized in } \\
\text { suspension of porous } \\
\text { microcarrier in batch } \\
\text { cultivations in spinner } \\
\text { flasks as well as in } \\
\text { fluidized bed reactor } \\
\text { in continuous mode }\end{array}$ & $\begin{array}{l}\text { DS data reflects changes in cell physiology and } \\
\text { could be correlated to cell metabolic activity. For the } \\
\text { continuous culture, this enabled a closed loop control } \\
\text { of the glutamine feed rate according to the metabolic } \\
\text { needs of the cells. }\end{array}$ & $\begin{array}{l}\text { [Noll and } \\
\text { Biselli, } \\
\text { 1998] }\end{array}$ \\
\hline $\mathrm{SP} 2 / 0$ & Perfusion process & $\begin{array}{l}\text { Excellent correlation of capacitance and cell } \\
\text { concentrations over a culture period of } 40 \text { days } \\
\left(2 \times 10^{5}-17 \times 10^{6} \text { cells } / \mathrm{mL}\right) \text {; mean size of a population } \\
\text { changes in response to media changes, possible } \\
\text { detachment of adherent growing cells from the } \\
\text { surface, substrate limitations and osmotic stress. The } \\
\text { correlation between capacitance and live cell number } \\
\text { is lost, when the dielectric properties of the cells } \\
\text { change (for example due to substrate limitation or } \\
\text { osmotic stress). }\end{array}$ & $\begin{array}{l}\text { [Carvell and } \\
\text { Dowd, } \\
\text { 2006] }\end{array}$ \\
\hline $\begin{array}{l}\text { Vero producing } \\
\text { rabies virus }\end{array}$ & $\begin{array}{l}\text { Batch, perfused, with } \\
\text { animal component } \\
\text { free medium on } \\
\text { Cytodex1 in a } 2 \mathrm{~L} \\
\text { stirred tank reactor }\end{array}$ & $\begin{array}{l}\text { Linear correlation between the permittivity and viable } \\
\text { cell concentration for the growth phase and virus } \\
\text { production phase. Cell lysis monitoring by critical } \\
\text { frequency calculation using the cole-cole model. }\end{array}$ & $\begin{array}{l}\text { [Rourou, et } \\
\text { al., 2010] }\end{array}$ \\
\hline
\end{tabular}

